\title{
The Future Initiatives of Smart communities in Baghdad as a Smart City
}

\author{
Noor Al-Kamoosi ${ }^{1}$, Mohammed Qasim Al-Ani ${ }^{2 *}$
}

\section{Authors affiliations:}

1) College of Engineering, Al-Nahrain University, Baghdad- Iraq alkamoosinoor@gmail.com

$2^{*}$ ) College of Engineering, Al-Nahrain University, Baghdad-Iraq mohammedkassim66@yahoo. com

\section{Paper History:}

Received: $13^{\text {th }}$ June 2019

Revised: 31th July 2019

Accepted: $17^{\text {th }}$ Nov. 2019

\begin{abstract}
Today, our cities are facing a host of challenges to accomplish the quality of life or their inhabitants. On the one hand, city planners and architects seek to preserve heritage, habits, and city peculiarities. On the other hand, it is necessary that the city is kept abreast of the rapid changes in Information and Communications Technology (ICT), Internet of Things (Io'T), Artificial Intelligence (AI) and smart city concept. In Baghdad, it could be observed that there are several activities based on community initiatives, awareness campaigns, and initiatives which are self-funding from youth or funding from NGOs, and INGOs. How can we invest in such initiatives to achieve a smart city, emphasizing that the city is for the people, not a city of things? As we know that smart cities have six factors: smart (economy, governance, environment, people, mobility, and living).
\end{abstract}

This paper assumes that smart communities are the seventh factor of smart cities factors which could play an essential role to apply the smartness in Baghdad. In this case, it will help to achieve making decisions and a feedback evaluation system will be subject to transparency, openness, vitality, and sustainability because it will stem from the community and ensure the sustainability in a smart city.

Keywords: Smart City, Smart Community, Community Initiatives

$$
\begin{aligned}
& \text { المبادرات المستقبلية للمجتمعات الذكية في بغداد كمدينة ذكة } \\
& \text { نور ضياء القاموسي، محمد قاسم عبد الغفور العاني } \\
& \text { اليوم، تواجه مدننا العديد من التحديات في سبيل تحقيق جودة الحياة لساكنيها. من جانب، يسعى المخططين }
\end{aligned}
$$

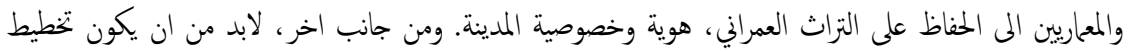

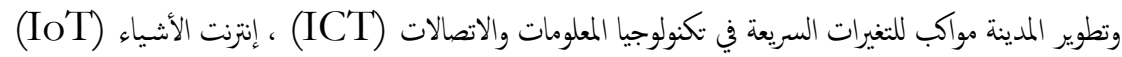

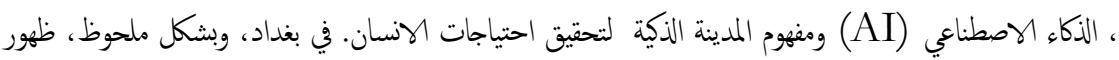

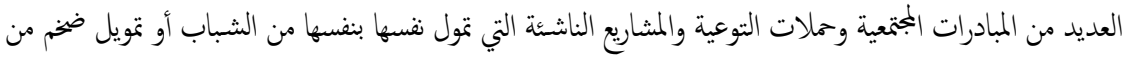

$$
\begin{aligned}
& \text { المنظلات غير الحكومية المحلية او الدولية. }
\end{aligned}
$$

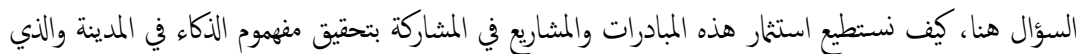

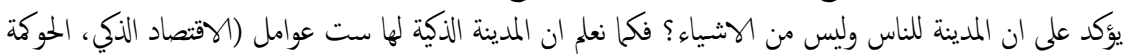

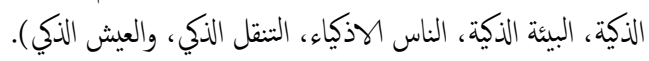

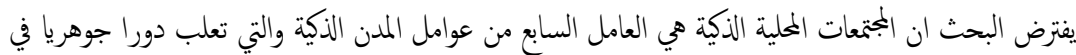

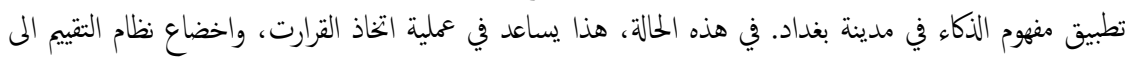

$$
\begin{aligned}
& \text { الشفافية، والانفتاح، والحيوية والاستدامة لانه سيكون نابع من المجتع وهذا اهم ما يحقق الاستدامة في المدينة الذكية. }
\end{aligned}
$$

\section{Introduction}

The future is a time yet to come, the future life in our city depends on what we did in the past, which we always seek to preserve its value, and how we live in the present and work to sustain our resources. Any decision making, initiatives, new ideas, ventures, 
actions or changing the states are reflected in the life of our next-generation. Therefore, it is necessary that urban designers, planners, and thinkers take into account analyzing the status quo and identify the main problems, knowing the real affected and effected people, and finding the solutions to meet human needs from a future perspective by investing the resources, as well as making short-term and long-term plans. Frank Chimero (2012), is a designer and the author of The Shape of Design Book, said: "People ignore design that ignores people."

Each city, which of Baghdad is one, is facing different levels of problems (local, regional and global). Moreover, each city has its unique characteristics that differ from other cities; it has strengths to be invested and weaknesses to be developed. The globalization, with its advantages and disadvantages, has to invade our world. The Cities are facing the rapid changes in Information and Communications Technology (ICT), Internet of Things (IoT), Artificial Intelligence (AI) and the smart era.

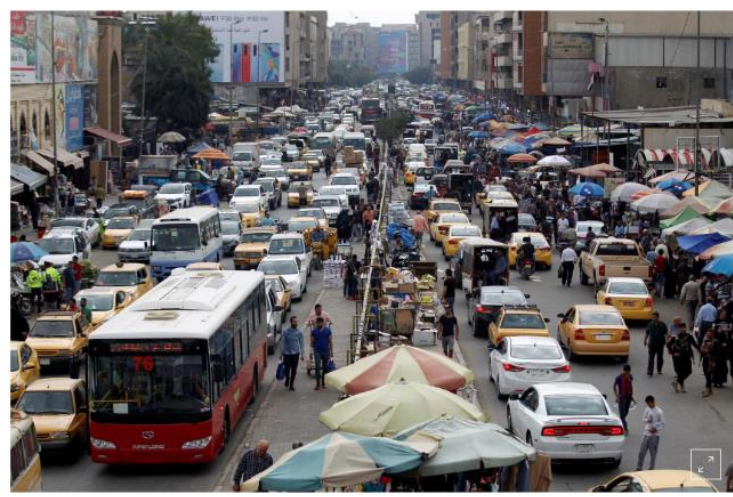

Figure 1: Life in Baghdad

The information and news are rapidly carried from the Far East to the west, creating a rapid rhythm in our lives. We may lose small details of life in the future yet miss human connectivity. We focus our attention on what is going on globally and forget our local problems which led to the accumulation of what is under our feet and in front of our eyes. If people could solve many of their local problems first, then solving global problems will be easier later on.

Let's assume that we have two smart cities scenarios for Baghdad. In the next 30 years, the first has made things a priority, and in the other, people are made a priority in achieving their smartness. In the city of things, streets will be without people; robots, currently cars, will fill the streets and make the connectivity instead of people. Each person will perform his duties and meet his needs while he is lying on his couch most of the time in rooms resembling small boxes, communicating with others using smart screens. The scale of the city will be compatible with things scale, not human scale, because of the city of things. Are these practices in line with the 2030 Agenda of Sustainable Goals?

While in the city for people, streets will be full of human communion, and the inhabitant will feel comfortable, happy and safe. Dealing with the scale of buildings, spaces and streets will be more humane. The interaction between people and physical or virtual features will create the spirit of places. People will feel a sense of belonging, and that they are as part of these places. They will be more active and creative. They could reach to the top creativity and use the technology. They will create their past for the future.

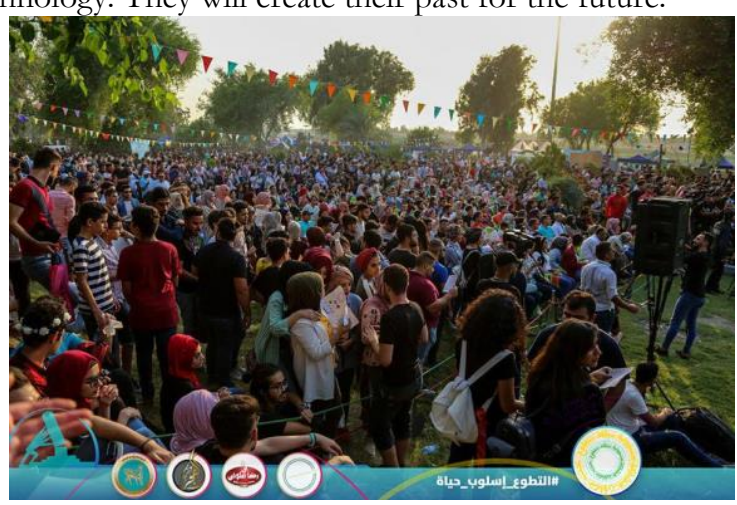

Figure 2: World Peace Day Carnaval 2018 -

Baghdad

At the same time, we could notice that different small communities are being formed for different interests in several aspects and specialties. These communities do not hinder the geographical area much as it is concerned with solving their cities' problems, enhancing their roles in making the decisions and expressing their opinions or attitudes, or activating any aspects of their life such as in arts, heritage, laws, sport, etc... This point is important when investing in smartness concepts.

This paper reviews the seven main factors of smart city (Economy, mobility, environment, governance, living, people, and community) with focusing on the role of smart communities in each of the other six factors, especially in Baghdad. It assumes that achieving a smart city in Baghdad must be through revitalizing the role of smart communities in the city.

Jane Jacobs (1961) said "Cities have the capability of providing something for everybody, only because, and only when, they are created by everybody." (Jacobs, 1961, p. 238) This research confirms that smart cities have the capability of providing something for everybody, because, and when, they are created by smart people as a part of the community. Assuming that community initiatives play an active role in the future of Baghdad as a smart city.

Most of the researches deal with the characteristics of a smart city from a technological point of view and that leads us to focus on the smartness of things and ignore the smartness of people, therefore consider the communities a result of using the smartness of technology as a tool of connectivity. Whereas if we treat people as a priority during our planning for the Smart City, we will create more sustainable connectivity than using the technology.

This paper will address the role of future initiatives of community in Baghdad which is an important catalyst to achieve sustainability in the smart city through dealing with the seven factors that are mentioned above. In the beginning, it's important to explain the difference between (smart \& intelligent) and (community \& society). Second, it will deal with the literature reviews of smart city with emphasizing 
on smart people. Thirdly, it will review the smart communities by focusing on examples in Baghdad.

\section{Differences}

\subsection{Smart vs. Intelligence}

The origin of Smart term is derived from "Middle English smerten, from Old English smeortan "to smart", from Proto-Germanic smertaną (to hurt, ache), from Proto-Indo-European (s) merd- (to bite, sting)." ( Merriam-Webster, 2018) This term has many uses to describe people, things and sometimes it describes the actions of people or machines. In Oxford Advanced Learner's Dictionary, smartness is defined as "intelligence as manifested in being quick and witty." (Turnbull, 2010, p. 1454)

While, the origin of intelligent is derived from "Latin intelligent-, intelligens, present participle of intelligere, intellegere to understand, from inter- + legere to gather, select" (Merriam-Webster, 2018) Intelligence is used to describe "the ability to learn, understand and think in a logical way about things." (Turnbull, 2010, p. 810)

After presenting the meanings in official dictionaries, we notice that 'smart' is a more comprehensive term than 'intelligent'. Smart indicates "the ability to make good business or personal decisions" whereas 'intelligent' indicates "the ability to think." (Turnbull, 2010, p. 810)

Clarifying the difference between the two words above is very important. We can notice that when associating those two words with other words, such as cities, buildings, systems, governances, and communities. Also, it will be noted that "we use 'smart' when describing a group than the individual. Smartness occurs when the relations between things or people actions are quick, systematic and more professional. We see smartness used in the higher level or layer of relation that individuality." (Al-Kamoosi \& Al-Ani, 2019, p. 782)

Also, it was mentioned that "the terms smartness or intelligence usually represent an individual mental ability. Human intelligence has some key specifications like perception, communication, learning, memory, and planning. Artificial intelligence is the study of intelligent components that perceive their environment and make the right decisions." (Aggarwal, 2019, p. 659)

\subsection{Community vs. Society}

In OXFORD Advanced Learner's Dictionary, community defines "as all the people who live in a particular area, country, etc." Or it means "a group of people who share the same religion, race, job, etc." (Turnbull, 2010, p. 301).

From 1887, Ferdinand Tönnies ${ }^{1}$ discussed the differences between (Gemeinschaft und Gesellschaft) or (Community and Society) and defined community

${ }^{1}$ Ferdinand Tönnies “"(1855- 1936) was a German sociologist and philosopher. He was a major contributor to sociological theory and field studies, best known for his distinction between two types of social groups, Gemeinschaft and Gesellschaft". "as groups of people who share common interests, beliefs and values and who may interact only in some mediated way (through the Internet, for example) are described as communities when the term (voluntary association) is more appropriate." (Bruce \& Yearley, 2006 , p. 44) Also, a community can also be defined "by describing the social and political networks that link individuals, community organizations, and leaders." Benjamin, 2011, p. 5).

While the term of Society is known in OXFORD Advanced Learner's Dictionary as "people in general, living together in communities." (Turnbull, 2010, p. 1464).

According to the above, we can observe that society is a group of the community but the community is a group of individuals. Society is constant even if people change. After a while, the community is changeable, flexible and updated. Common area, in the concept of society, is required, in contrast to the community, the common area is not required and sometimes it may be intangible.

After reviewing these differences between (Smart \& Intelligent) and (Community \& Society), they lead us to conclude the definition of smart community:

A smart community is a group of connected people who share the common interests, ideas and beliefs, whether they are the same place or not. They communicate and interact to achieve common goals among themselves whether through the Internet, volunteer works, or community activities.

\section{Smart city:}

Through the comparison above, the term Smart denotes be more connected. It indicates that the smart city is a connected city but how can we make it perfect connected? This question leads us to study the emergence of a smart city.

Ryser said in REAL CORP Conference 2019 that "Views differ on the origins of the smart city movement. Some relate it back to the introduction of traffic lights at the beginning of the 20th century; others refer to Los Angeles and its high tech context when as early as the 1960s the city administration constituted the Community Analysis Bureau with a computerized database; others situated it in 2005 when the (sustainability connected urban development program) of the Clinton Foundation supported Cisco R\&D which Cisco used in 2010 to create its (Smart and Connected Communities Division) to commercialize its products. Amazon created AWS (Amazon Website Services) to power smart, connected and sustainable cities. Later, other global tech firms connected with the smart city movement. For example, Google created its (Sidewalks Lab) in 2017 led by Daniel Doctoroff2." (Ryser, 2019, p. 161)

2 "Daniel Louis Doctoroff (born July 11, 1958) is an American businessman and former government official. He is the chief executive officer of Sidewalk Labs, a startup company focused on developing technology focused on city life." Invalid source specified. 
In general, most studies dealt with smartness in the city from a technological viewpoint. It makes people think of technology as the main idea of a smart city, making it a goal that seeks to advance cities to be smarter and smarter in a purely economic race. While using smart people as a characteristic of a smart city is to describe the connectivity in the cities. Connected people are more interactive and communicative.

If the concept of smart cities really contributes to achieving the Sustainable Development Goals (SDGs), especially the $11^{\text {th }}$ goal (Sustainable cities and communities). It should be worked to provide sustainable systems and focus on the connectivity between people.

"Cities, it is argued, will have become smart when investments in human and social capital, traditional (transport) and modern ICT (first uses of the term at the end of 20th century) and -infrastructure fuel sustainable economic growth and a high quality of life, with a wise management of natural resources, through participatory governance" (Counsell, 2017, p. 41)

To achieve sustainability, it needs sustainable people and places. Sustainable places must be connected places and could reflect the past, present, and future for their users. The $11^{\text {th }}$ goal of SDGs indicates to (United Nation, 2018)

- "Safe and Affordable Housing.

- Affordable and Sustainable Transport Systems.

- Inclusive and Sustainable Urbanization.

- Protect the World's Cultural and Natural Heritage.

- Reduce the Adverse Effects of Natural Disasters.

- Reduce the Environmental Impact of Cities.

- Provide Access to Safe and Inclusive Green and Public Spaces.

- Strong National and Regional Development Planning.

- Implement Policies for Inclusion

- Resource Efficiency and Disaster Risk Reduction.

- Support the Least Developed Countries in Sustainable and Resilient Building"

Our cities are facing a host of challenges to achieve the quality of life for their inhabitants. Challenges lie in cities in preserving the past while using smart technology in the present and saving for the next generation in the future. The city is a complex system and dealing with this complexity requires more flexibility and resilience to create an integrated system, also to achieve the connectivity and smartness between urban systems.

The sustainable urban system always needs to sustain itself and also to be updated. It requires involving the people in this system. The urban system is from people to people. Updating in the sustainable system is happening by feedback. "A feedback loop is the means of soliciting citizens' input and involvement in public safety matters in order for the local government to understand the city better. Linking the

${ }^{3}$ Beniamino Murgante is a professor of Urban and Regional Planning at the University of Basilicata.

4 "Michael Frank Goodchild (born February 24, 1944) is a British-American geographer. He is an Emeritus Professor citizens and the local government directly with their services is the evident advantage of the feedback loop. The purpose of a feedback loop in a smart city is to assist the local government to put first the needs of the citizens and satisfy the cities they service by transforming words into deeds." (Gopeni, 2016, p. 8) The socio-technical feedback loop system has two types of feedback loop: Negative and Positive.

Beniamino Murgante ${ }^{3}$ (Smart city or Urban Science) said in REAL CORP Conference 2019 that the base of a smart city is governance and regulation, which stands on three pillars in Smart City: Connections, Open data, and Sensors. And Michael Goodchild ${ }^{4}$ said that citizens are as voluntary sensors who could feed the system with information and participate to make the decisions in their city. Murgante, 2019, pp. 15,18)

In a Smart City, people play a double-Coded. They are influential and affected. Without people, there is no smartness in the city, and also, achieving a smart city is important for a decent life for people. Michael Batty $^{5}$ (2017) said through his speech in TEDx London that "the city will be smart as its citizens." This relation creates big challenges which any city could face through moving to smartness era. People are different and dealing with them through planning needs flexibility, resilience, and wellbeing. Through focusing on six factors of a smart city. People are involved in most of their indicators.

After the glorification and encouragement of the Smart City, recent studies become to criticize it. This is normal because we began to reap the fruits of this idea and touch its positive and negative effects. The problem is not of the general idea of Smartness, the problem is with the priorities that have been focused on applying the idea.

"Technology is the tool to make a city smarter, yet becoming a smart city is not only a goal, but a means to an end: the entire point lies in responding more effectively and dynamically to the needs and desires of residents, especially to the most vulnerable people in our cities: elderly, children and disabled people." (Khalilnezhad, 2019, p. 60).

"There are five elements necessary to achieve the goals of a smart city. These are to establish: (Zhu \& Dai, 2017, p. 2)

1. A civic innovation lab using collaborative technologies;

2. Open data and platforms to mobilize collective knowledge;

3. Human behavior;

4. Investment also in smart people;

5. Collaborative technologies for all parts of society."

And also, the researchers (2009) confirmed that "smart cities as cities that achieve the sustainable development which incorporates the social capital, traditional and modern ICT infrastructure, by effective

of Geography at the University of California, Santa Barbara." Invalid source specified.

${ }^{5}$ Michael Batty " (born 11 January 1945) is a British urban planner and geographer, and a Professor in The Bartlett at University College London.” Invalid source specified. 
management of the natural resources and participatory planning." ( PIRACHA \& KUMAR, 2017, p. 2)

Also, it was mentioned that "The smart city is constituting a new leitmotif in urban planning, which succeeds, overlaps with and complements previous leitmotifs, such as the creative, intelligent or global city. While visions are future-oriented, they are elaborated, diffused, or discussed in the present and the promoters of rivaling visions compete for public attention and economic resources for their realization.

These preliminary considerations demonstrate that visions and leitmotifs for urban futures frame presentday negotiations over urban issues, for example by

empowering technology-centered paradigms for urban development. Visions and leitmotifs also impact the presence by affecting anticipatory changes in urban cultural practices that adapt to an expected future, for example in the sense of re-evaluating notions of urban comfort and urban risk. This motivates our analysis of urban smartification to concentrate not only on the material aspects of smart urban technologies but to consider these as sociotechnical and historical phenomena that are subject to change over time." (Ottenburger \& Ufer, 2019, p. 63)

There are three ways to define the smart city, it will be explained in the table (1-1) below:

Table 1-1: The Framework of Smart City definitions by Author According (Aggarwal, 2019, p. 660)

\begin{tabular}{|l|l|l|}
\hline \multicolumn{1}{|c|}{$\begin{array}{c}\text { Smart City } \\
\text { framework }\end{array}$} & \multicolumn{1}{|c|}{ Definitions } & \multicolumn{1}{c|}{ Indicators } \\
\hline $\begin{array}{l}\text { Technology-oriented } \\
\text { vision }\end{array}$ & $\begin{array}{l}\text { "Interconnects to promote optimum performance \& efficiency to } \\
\text { create 'systems of systems' and are based on core-system which are } \\
\text { composed of networks infrastructures, environments for citizens and } \\
\text { city services." }\end{array}$ & $\begin{array}{l}\text { Optimum Performance } \\
\text { System of Systems } \\
\text { Smart Infrastructure } \\
\text { Smart Environment } \\
\text { Citizen and city service }\end{array}$ \\
\hline $\begin{array}{l}\text { Approach-oriented } \\
\text { vision }\end{array}$ & $\begin{array}{l}\text { "consists of dimensions of Smart Economy, Smart Governance, } \\
\text { Smart Mobility, Smart Environment, Smart People and Smart Living } \\
\text { for self-decisive, independent and aware citizens" }\end{array}$ & $\begin{array}{l}\text { Smart Economy } \\
\text { Smart Environment } \\
\text { Smart People } \\
\text { Smart Living } \\
\text { Smart Governance }\end{array}$ \\
\hline $\begin{array}{l}\text { Service-oriented } \\
\text { vision }\end{array}$ & $\begin{array}{l}\text { "Empowers the collective intelligence and in co-creating capabilities } \\
\text { of the users while encouraging co-operative strategies of the 4P } \\
\text { model public, private, people and partnership." }\end{array}$ & $\begin{array}{l}\text { Empowerment } \\
\text { Co-Creating capabilities } \\
\text { 4P (Public, private, people } \\
\text { and partnership) }\end{array}$ \\
\hline
\end{tabular}

According to the above, it could be noticed that dealing with the concept of a smart city that differed from study to another but at the same time, most of them emphasize the quality of life and citizen services. Also, they asserted that the smart city goals encourage the concept of sustainable. So far, no one objects to these two things ... So where is the problem?

The problem lies in smart city applications and its implementation on the reality. It is not easy to convert the theoretical concept to the practical project, especially when we speak of a city of historical value inhabited by millions of people and their needs must be met as soon as possible. It is necessary to mention global economic competition with political conflicts. All of that affects city planning. As long as technology plays the biggest role in this occupation of our world, it is certain that smart cities applications will be guided by a technological perspective. This thought alone is worrisome if we look at the cities as a city of things and forgot the people living in them.

\section{How could Baghdad be a smart city?}

After 2003, Iraq became more open to the world, suddenly and without planning. Because Baghdad is the capital, it and its people have undergone major changes in recent decades as a result of internal and external factors in all fields and at various levels. The city was exposed to economic, political and social crises, wars, terrorism, insecurity and displacement, unplanned population and housing growth, slums, weak law, and legislation, floundering urban planning, financial and administrative corruption, and unemployment. An open economic market and rapid technological developments have made people flounder between the old and the new, learning and coping at the same time, trying to absorb this storm. All that has positive and negative effects at the same time.

In the Annual Statistical Report from Iraqi Ministry of Planning, Iraq population in 2018 is about 38 million and (40.2\%) aged between (20-54) years old. (Iraqi Ministry of Planning, 2017, p. 61).

These ratings measure the quality of life residents and the level of services provided by the government to people. There is a huge gap between the government and the residents. It has created a lack of trust among them and a state of despair among the citizens because of (top-bottom) decision making. After the negatives stated above, we ask: How could Baghdad be a smart city by people?

Many studies and proposals are working to solve Baghdad's problems like the Comprehensive Development Plan for the City of Baghdad 2030 of Khatib and Alami Study.

Below we can perceive the main seven factors of a Smart City according to Giffinger \& Fertner Studies with focusing on the role of community in each of them through the examples that exist in Baghdad to recognize the indicators that lead us to Baghdad as a Smart city.

\subsection{Smart City Factors:}

There are many studies that have dealt with smart cities and came out with indicators that may be very similar, with some differences in the labels, but the most commonly used is the study of Giffinger and Fretner (2007). In 2019 (Real Corp Conference), Al-Kamoosi 
and Al-Ani classified the Smart City indicators to who focusing on a thing or people or both. There are 6 main factors, 31 secondary factors and 74 indicators in the table below (1-2), 28 indicators are found focusing on things as a priority, 35 indicators focusing on people, and 11 indicators focusing on both.

Table1-2: Classification of Smart City Indicators between (people \& things) By Authors according to (Giffinger \& Fertner, 2007) \& (Al-Kamoosi \& Al-Ani, 2019)

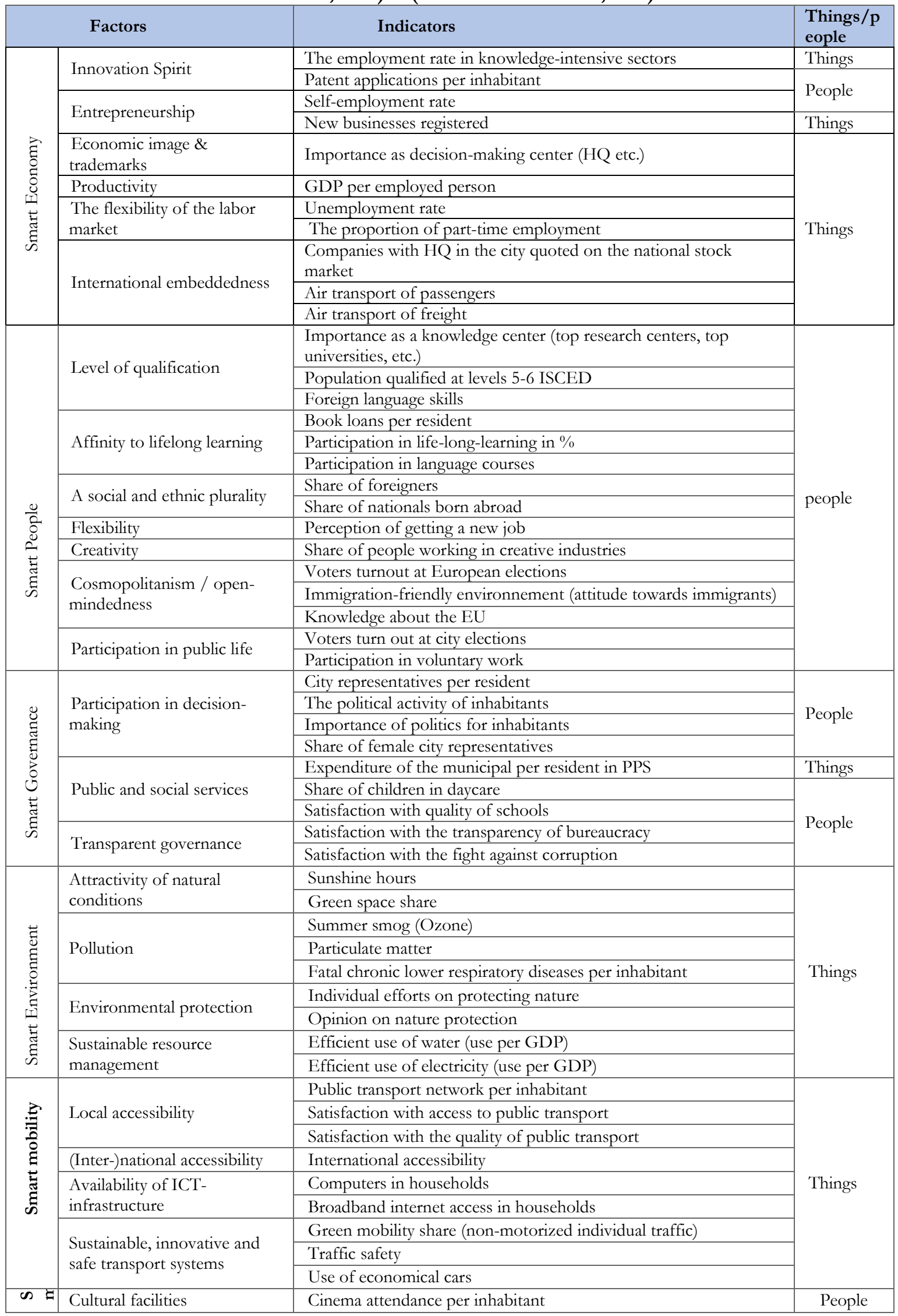




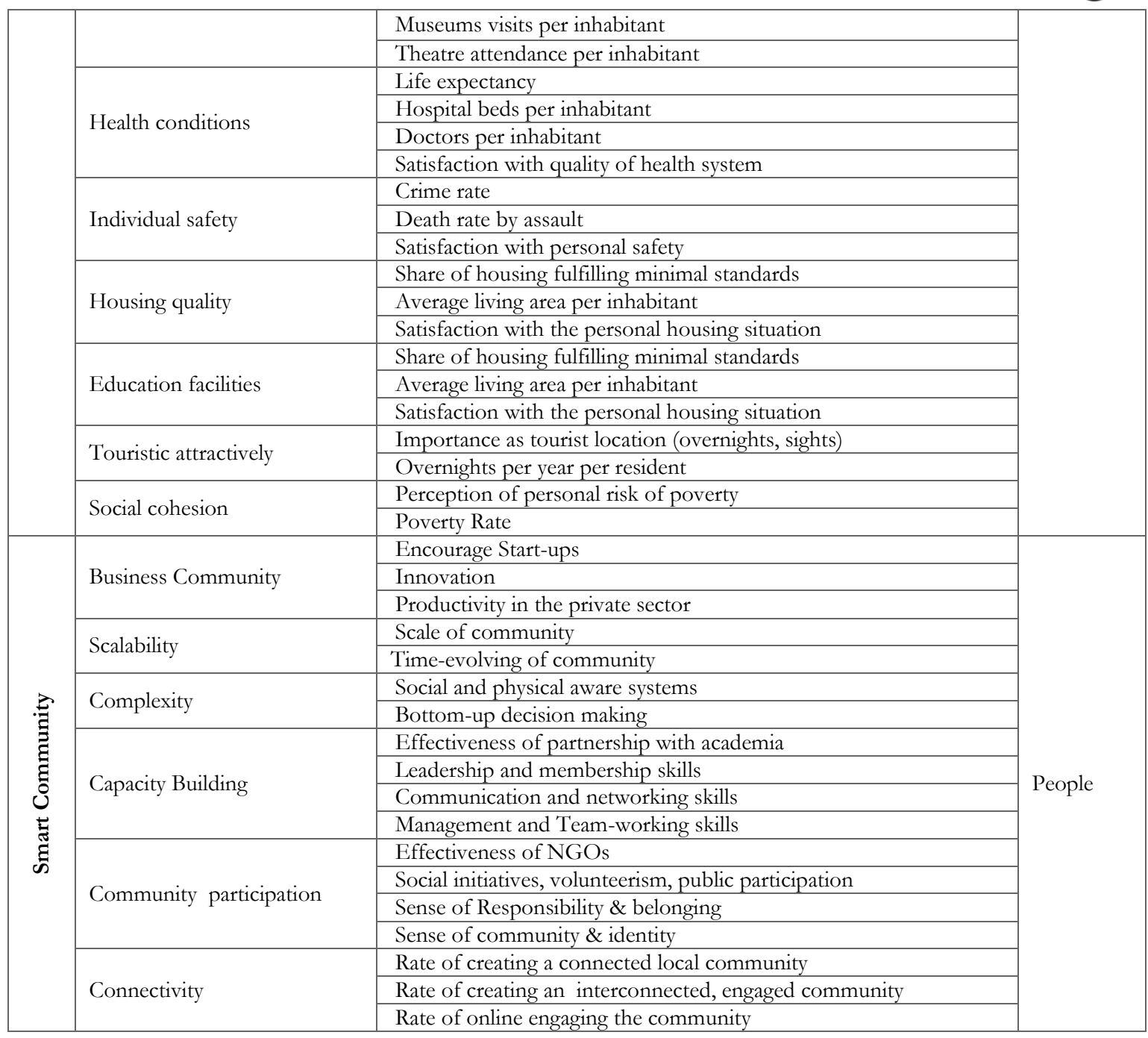

\subsubsection{Smart Economy}

Economy powers consider the strongest engine that controls political, social and environmental aspects. Economy touches the human daily life and affects the joints of cities from large businesses to small initiatives. Any city has three sectors; private, public and common sectors.

"Challenges in the Smart Economy action field are related to the productive structure of the city. After the economic crisis, urban regions have understood the convenience of not focusing their productive model on just one economic sector. Enhancing the creation of a multi-sectoral economy would make cities more resilient to economic downturns, exploiting the unique conditions of each urban agglomeration within a certain region and interconnecting their productive networks can improve this resistance." (Monzon, 2015, p. 22)

Smart Economy has 7 factors and 13 indicators. They focus on people and things at the same time. According to table (1-2), smart economy focuses on people and things. In Iraq, entrepreneurship and the spirit of innovation can focus on achieving a smart city for people. The above statistics indicate that Iraqi youth's thinking should be directed towards the idea of self-employment and creating innovative projects that solve the problems of life rather than work in the public sector.

"In 2012 alone, the reported total labor force in Iraq was nearly 8.2 million, a 25\% increase from 1994. In 2017 it was reported that nearly 8 million Iraqis work in the public sector alone in addition to 8.1 million Iraqis work in the private sector. With nearly $11 \%$ of the total available workforce in the country is unemployed. The general median age in Iraq is 20.2 years with nearly more than $65 \%$ of the total population below 30 years old. The numbers show clearly that in the next 10 years, the labor force numbers shall keep going up. This increase shall propose some challenges in terms of providing enough educational entities to educate these segments of the population, enough medical institutes to serve the population and of course enough jobs to be created to cope with this vertex. The current population numbers stand around 38 million Iraqis with a promising increase to 58 million in the coming 20 years." (ALHILLY, 2018, p. 1)

To achieve a sustainable smart economic system, there must be effective joint action between the public 
and private sectors, stakeholders and beneficiaries. The stakeholders of any city play the main role to sustain the economic system in the city. Especially when the government priorities are the military sector; fighting terror and improving security. Therefore, the people role become larger to sustain at least the economic aspects by entrepreneurship and create new business and self- employment.

Entrepreneurship means "the process of creating something new with value, particularly responding to the opportunities available. It involves time, efforts and assumption of risk, with the expectation of receiving the rewards at the end. The rewards can take any form- monetary or non-monetary (personal contentment).” (Pahuja \& Sanjeev, 2015, p. 8)

Iraq witnessed in the last years increasing the concept of entrepreneurship, new initiatives and small business projects that will lead us to find the suitable base to think about self-employment. In table (1-3) the important stations that we must focus on will be explained because it could be considered the first Iraqi initiatives founded by the community, especially Iraqi Youth.

Baitoona, Innovation for Development, Hilli, initiative Weekend and others, see table (1-3), are Iraqi initiatives that focus on the concept of entrepreneurship and innovative spirit. How could Iraqis young depend on themselves to start their own projects and be in line with the economic wheel in Baghdad. Nowadays, some of these projects, like Hilli, is scaled up to be a medium business after it was a startup because it develops and covers the market needs of products and services.

Iraqi youth began to improve themselves by volunteerism, participation in workshops and courses in leadership and communication forms, and teamwork. That means that the next generation has the ability to play a good role in economic development.

It requires both sectors to support such projects and facilitate their mission to ensure a thriving economic market for the next generation. Investment of youth in economic decision-making will re-energize and stimulate the economy and foster confidence among the large, medium and startup companies.

\subsubsection{Smart Government}

Smart governance has three factors: Participation in decision-making, public and social services and transparent governance. "The main challenges that cities face in the Smart Governance action field are related to the urgent need for a change of government model. Governance models will face the challenge of making themselves more flexible allowing to combine their top-down policies with bottom-up initiatives and also with informality. Demographic changes and territorial cohesion are the other two main challenges to face" (Monzon, 2015, p. 22)

As mentioned above, it can be seen that achieving sustainable smart governance depends heavily on stakeholder participation. Smart participatory needs people awareness and create the smart people base that trait of leadership, teamwork, and communication skills. They have the motivation for new projects, flexibility and creativity, and openness to new ideas, innovation and open-minded.

"Smart governance is an advanced form of egovernance. It is about making the right policy choices and the implementation of same. The knowledge society should give a set of elements for smart governance that is open to sharing information and its use, transparent decision making, collaboration and participation of stakeholders, improvement in government services, and operation through the use of intelligent technologies." (Gupta, et al., 2017, p. 25)

The urban policymakers always focus on data policy and regulation in data and service layers of the smart city. It has been mentioned that cities are transformed into smart cities through (Transportation, consumer, ownership) to (Mobility, prosumer, usership), respectively. This transformation requires to configure a sustainable human base that possesses the skills and awareness of people to participate in decision-making and to achieve a satisfactory quality of life for themselves. Usership and prosumers are most sides that touch the sustainability of human life.

If we focus on smart governance in Baghdad or Iraq, we will find that the role of community and people are limited through two aspects. Firstly, through the elections, and secondly through Social media. There is a huge gap between people and government and people don't trust either the government or parties.

If there is anything that unsatisfied them, they are only content to announce their rejection through electronic comments and posts on Facebook and twitter. Sometimes, Government respond to people's needs shared on Social Media about the elections process, people don't have enough awareness to understand the process and mechanism. Also, the Iraqi government lacks strategic planning to achieve smart governance. One of the most important factors to achieve a smart city is to have smart governance.

\subsubsection{Smart Environment}

Smart environment indicators: Attractive of natural conditions, pollution, environmental protection, and sustainable resource management. "In the Smart Environment action field, different challenges related to the built and natural environment can be found. On one hand, there is a need for reducing land consumption for the extension of our cities. Avoiding urban sprawl and looking for more dense and livable cities will enhance a mix of uses and the concentration of population, reducing the use of the car. On the other hand, the reduction of energy consumption, pollution, and $\mathrm{CO} 2$ emissions is a growing ecological demand for achieving sustainable development." (Monzon, 2015, p. 22)

People play a role in achieving the smart environment, especially in the awareness, consulting, data collection and also in the implementation process, but most importantly is their role in a sustainable use, reuse, and waste management. If the community doesn't have the skills to reuse and recycle or healthy awareness and reduce pollution, government effort may be lost in vain. Environment initiatives are 
common initiatives from people by volunteerism and NGOs.

Waste management and recycling are not working if there is no community participation because of life cycle. In smart city studies and project, people are the consumer and the producer at the same time so they called them the prosumer. People have the right to access the data and observe their effects on the environment. That could help to increase the sense of responsibility in their cities to protect the next generation from the pollutions.

One of the social initiatives about the environment is Iraqi Social Forum which is an NGO that has several divisions in different aspects. One of them is called Saving Tigris (Humat Dijlah Association) that focus on water problems in Iraq and how we can protect from the contaminated water. They are working through social initiatives and voluntary works.

Also, there is a new startup that is called Nakhla. It was founded by three Iraqi youth to care and treat the existing palms in Baghdad and develop dates products.

\subsubsection{Smart Mobility}

Smart mobility is one of the most important characteristics that countries seek to achieve in their cities, if not the first. Because it affects and impacts all joints of life. If the mobility in the city is not efficient, it may cause environmental and pollution problems on one hand, economic and social aspects of the other. Mobility may be a standard for measuring the quality of life in the city and also good mobility is an attraction for tourism and economic exchange with the outside.

"Smart mobility means that the city should have national and international accessibility, using information and communication technologies (ICTs) to ensure that technology has been used widely during the design of national highways and bridges. Metros, monorails, and an intelligent transport system should be used for daily commuters. The urban design should be such that it gives importance to last-mile connectivity. The transport system should be sustainable and innovative. It should also take care of the safety of daily and occasional commuters within and outside the city." (Gupta, et al., 2017, p. 25)

It is a complex system that needs a good study of the real situation to achieve city needs, it is not necessarily using the most technologically advanced means to be smart, but must achieve communication and connection between the urban foci of the city in suitable ways and appropriate means to the privacy and nature of the area.

"Achieving a sustainable, inclusive and efficient mobility system for goods and people in the overall challenge to be dealt with in the Smart Mobility action field. Implementing a multimodal public transport system, fostering alternatives to the car-based mobility and making public transport reachable and available to all citizens are the three main axes that will allow reducing congestion and pollution in cities and improving connectivity." (Monzon, 2015, p. 22)

Holland mentioned in his article about the companies and business how the smart mobility has been "driven by the profit motive of global hightechnology companies, in collusion with the trend towards city governance being wedded to a competitive form of 'urban entrepreneurialism', has left little room for ordinary people to participate in the smart city." (Hollands, 2015, p. 61)

Smart mobility has four factors and 6 indicators. If we classify the indicators depending on the city for people or the city of things, we will notice that they focus largely on things rather than people.

Nowadays, smart mobility faces a range of responsibilities regarding ownership and legislation. Is it owned by the government, technological companies, or the public? Who has the right to access the data? And how can these regularities respect the right of users to privacy and ensure their safety?

Baghdad has many problems in Networks and transportations and these problems need large efforts from government and community. It is not easy to achieve smart mobility individually without government planning and community will. Most streets in Baghdad are not suitable for walking. The lack of law and regulation

\subsubsection{Smart Living}

In the city for people, smart living factors play the main role to achieve the smartness by/ for people. It could be noticed that 7 main factors and 20 indicators that "Smart living is characterized by diverse cultural facilities available to all kinds of religions, whether they belong to major or minor communities. Education facilities should be provided by establishing worldclass colleges and universities. It should also have tourist attractions as well as world-class hospitals with all the latest technology-enabled devices and equipment to allow a healthy lifestyle for every resident. Good quality housing, as well as social cohesion, should be provided to citizens of the city." (Gupta, et al., 2017, p. 25)

Smart living mentions investing people powers and skills to create a sense of community and belonging to the place through connectivity. "Knowledge, intelligence, and creativity are the pillars of human and social capital. Thus, informed, educated, and involved citizens, high quality of life, and the creation of a citizenry space are considered basic ingredients of the smart city." (Angelidou, 2017, p. 3)

When the focus is on people, not things, the considerations and the priorities will change, the standards and criteria will change in all respects. No one denies that human needs a life that is easier, faster, smarter and more sophisticated by using technology. But people care to design their life depending on humanity, be measured on a human scale, not on the scale of the car or machine.

If we return back to people initiatives in Baghdad and connect them with smart living indicators according to (table 1-3), it could be noticed that most of the initiatives or small projects that appeared in Baghdad, such as Baitoona, Daraj, Bil-weekend, Bait Tarikib, and Baghdad Downtown, are spotlighted on cultural facilities, housing quality, social cohesion, and tourism attractively.

The indicators of smart living show their direct contact with human life, their application reflect the quality of life in the city. See table (1-2) 
These projects and initiatives have contributed to increasing awareness of the importance of heritage and historical sites. The importance of the participatory role in protecting and reviving heritage is the responsibility of all. Encouraging the concerned parties, residents and users to take care of museums and heritage areas after increasing influx of visitors from Iraqi youth and families, and other tourists. For example, it convinced Iraqi National Museum authorities, located in Baghdad, to be open on weekends for the public.

They highlight the heritage buildings and tourist sites in Baghdad and Iraq in general and cultural activities in the theater and cinema in the platforms of social communication have helped spread and protect through campaigns to prevent the demolition or abuse.

People play an effective role to achieve smart living in their city.

It may be considered that the achievement of quality in education, health, housing, poverty reduction and protection of tourist sites is the responsibility of the authorities and governments alone, but they may be useless to the residents unless they contribute in achieving them. (Bottom-up) decision-making in achieving smart living depends largely on people's satisfaction, the nature of their needs and their sense of belonging to these places. Because it will achieve sustainability as long as users can participate. As have already been mentioned, the principle of the feedback loop in a smart city is essential to ensure its sustainability and effectiveness by/for people more than things.

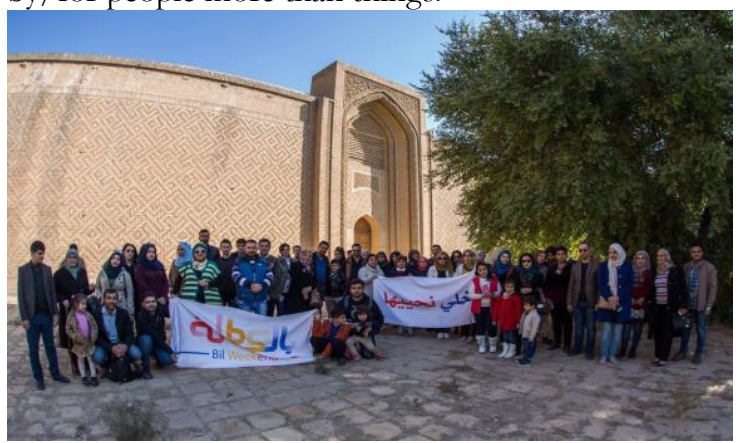

Figure 3: Bilweekend weekly tour- Abbasi PalaceBaghdad

\subsubsection{Smart People}

Many studies have discussed the concept of smart cities, most of them which dealt with the idea of smart people as the outcome of work on the other five factors. Today, we derive the product of this idea through smart cities that are designed and implemented and, as a result, formed cities of things. Modern studies and ideas have begun to emphasize the importance of the sixth factor (smart people) in achieving a smart city to focus on people and their role to apply the smartness in the city through "Improving social cohesion and quality of life are the main

6 "FFM is called The Big Five personality traits and the OCEAN model, is a taxonomy for personality traits. It is based on common language descriptors." challenges to face in the Smart People action field. An enriching community life is a final goal, and to achieve so, it is necessary to take initiatives to solve the high levels of unemployment in cities; as well as using the demographic movements and mix of population as an opportunity for innovation, taking into consideration all citizens independently of their age, gender, culture or social condition." (Monzon, 2015, p. 22)

It was indicated that creating "a smart city must be inhabited by smart people, and smart citizens, the need for smart communities, and ideas about the city as a learning machine and urban knowledge hubs." (Hollands, 2015, p. 75)

The main question that can be asked now is: what are the traits that people carry out to be smart people? (Especially, we explain the difference between smartness and intelligence).

In 2017, Advance of Smart Cities Book used the five-factor model (FFM) ${ }^{6}$ of Types and Christal in 1961 that are extroversion, conscientiousness, openness to experience, agreeableness, and emotional stability to find "the relationships between personality dimensions and job performance have been studied, and to show how people should behave and work smartly in a smart city in order to live a high-quality and luxurious life " (Gupta, et al., 2017, p. 26) According to these five traits, Smart people in smart cities are:

- Increased work performance, Smarter utilization of new ICT, infrastructure and Services

- Creation of a felicitous city, the city may flourish with a harmonious and happy atmosphere.

- Less chaos, activities are better organized, better planned, the city will grow successfully.

- The smart city will be able to cope with obstacles easily because of the optimistic, calm and stressfree characteristics of its citizens.

- Increase in innovation development of new technologies, better ideas to make the smart city more sustainable.

Smart people traits classify into: first, depending on personal skills for each person; second, depending on collective skills and communication between people. Both of them are very important for smart city ideas. Any Government could achieve smart mobility and infrastructure, smart houses and buildings, smart environment and smart governance, but all of that will never be sustainable if there are no smart people from the beginning.

Despite Baghdad's wars during the past years, and the suffering of its inhabitants from poor services, poor health, political conflicts, administrative corruption, and economic volatility, it is still a vibrant city.

Baghdad is a livable and vibrant city through its inhabitants. People continue to live, rejoice, celebrate, innovate and develop. The existence of the gap between the government and the residents has created 
an indirect incentive for people to initiate and carry out activities and projects without relying on the government. Some succeeded, some failed, and others still work to achieve their goals.

The culture of volunteering has never been prevalent among Iraqi youth before. After that, the idea began to spread among the graduates. They began to develop their skills through volunteering and participating in workshops and training. Now, it is noticed that students in junior high schools and universities are taking part in volunteer work and learning new skills in leadership, communication, teamwork, brainstorming, activities, and others.

In 2015, According to a statement issued by the Iraqi General Secretariat, all ministries and universities benefit from the adoption of the slogan: (Volunteerism is the responsibility of all to build the homeland.). Here, it could be noticed how people \& community could send an indirect message to the government of the importance of voluntary work.

In Table (1-3), there are many projects and initiatives depending on the concept of smart people more others. Firstly, most of the founders of these projects were volunteers in different social works in different aspects. They learned and improved their skills before starting their projects. Secondly, creativity, flexibility, level of qualification lifelong learning participation in public life and openmindedness could be founded through the projects, events, and activities. Such as TEDx Baghdad, Iraqi Builders, Innovation for Development, IQ Peace Network, Bait Tarkib, and others.

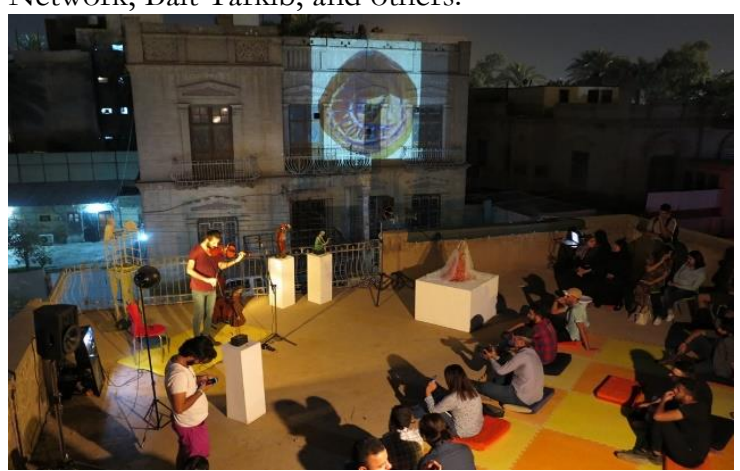

Figure 4 : Music event in the roof of Bait Tarkib Karadah - Baghdad

After the above, it is important to note that connectivity and communication among young people in Baghdad through activities, social works, volunteerism and events with using of technology as a secondary means which creates the smartness of people and as a result contributes to the realization of the smart city in a way that ensures its sustainability because it stems from the inhabitants and the users themselves. Here, people will move from consumers to prosumers.

\subsubsection{Smart Communities}

Smart Community was defined as a group of connected people who share the common interests,

7 "Silicon Valley is a region in the southern part of the San Francisco Bay Area in Northern California that serves as a ideas and beliefs, whether they are in the same place or not. They are communicating and interacting to achieve the common goals among themselves whether, through the Internet, volunteer works, and community initiatives and so on.

In Smart Communities Guidebook (1997), a "smart community is simply that: a community in which government, business, and residents understand the potential of information technology, and make a conscious decision to use that technology to transform life and work in their region in significant and positive ways." (International Center for Communications, 1997)

In 1998, Industry Canada defined a "Smart Community should be defined as a community ranging from a neighborhood to a nation-wide community of common or shared interest, whose members, organizations and governing institutions are working in partnership to use information and communication technologies to transform their circumstances in significant ways." ( MacDonald, 2000)

"The Smart Communities phenomenon is global in the sense that it exists all over the world as well as local since it is often based on local initiatives. It was first used in 1993 in Silicon Valley ${ }^{7}$, California when the area experienced a recession that was deeper than the national economic downturn, and predicted to last longer. Silicon Valley business leaders, community members, government officials, and educators decided together to help jump-start the region." ( Lindskog, 2005, p. 1)

According to the above, it could be concluded that smart community term mentions three aspects. Firstly, it is political; secondly, it is technological; and thirdly, it is social.

It can be noticed that the linkage between the connectivity by people and the connectivity by technology and how they play a good role in decision making. Community participation will create transparency and trustiness, will decrease the gap between people and their governments. The interaction and connectivity will create a sense of community and sense of belonging that assuring sustainability.

In the introduction to the Smart Communities Guidebook (1997), Pete Wilson said the "smart community concept says that local leaders know far better than State or national officials how nextgeneration technologies can best be marshaled to a community's benefit. It says that only local political, civic, business, and education leaders, working in cooperation, can bring people and technology together in time to capture the competitive and civic advantages that the telecommunications revolution makes possible." ( Lindskog, 2005, p. 5)

In Baghdad, the community lacks effective local leaders, not because individuals are not qualified to be leaders in their society, but because of their limited powers, weak laws protecting them, and political power over them. media."'Invalid source specified. 
Today, the stakeholders have the freedom to express their opinion or to highlight any phenomenon that may be accepted or rejected through social media platforms, and that is a healthy phenomenon. But at the same time, this needs to be answered by the local authorities which are more in contact with the community.

JSCA ${ }^{8}$ booklet (2015) mentioned that "Smart Community is a next-generation social system that adds richness to energy and community. It does not consist of a single technology but is an aggregate of systems where various stakeholders make active efforts for the development of Smart Community." (JSCA, 2015, p. ii)

In 2003, Smart Community International Network (SCIN) defined a "Smart Community is a community with a vision of the future that involves the application of information and communication technologies in a new and innovative way to empower its residents, institutions, and regions as a whole. As such, they make the most of the opportunities that new applications afford and broadband-based services can deliver - such as better health care delivery, better education and training, and new business opportunities." ( Lindskog, 2005, p. 3)

While some researches defined the "smart communities as a group of connected (social) objects that interact with each other over ubiquitous networks and deliver smart services to possibly all members. And they saw that smart community is an emerging area that features integration and coordination of the cyber, physical, and social worlds and that makes possible for us to build communities that are smart." (Xia \& Ma, 2011, p. 4)

In addition, Australian Smart Community is defined as: "Smart Communities are communities with a vision of the future that involves harnessing the power of the Internet and other ICT technologies in new and innovative ways to empower their residents, institutions, community groups, and businesses." ( Lindskog, 2005, p. 3)

Most of the above referred to the concept of Smart communities from a technological point of view. Now we will see the urban planners, architects, and sociologies that defied the smart communities.

In ISOCARP Conference 2017, one researcher defined "smart communities as the bonding between the smart city and intelligent buildings. The tangible part of intelligent buildings and the intangible management towards IoT, ITC, and neighborhood, etc, connect into the smart communities, and then a smart city with other elements." (Zhu \& Dai, 2017, p. 2)

"The smart community has created innovative solutions for the crowded urban life, which has brought about fundamental changes in the communication between the urban public. It is the full

\footnotetext{
${ }^{8}$ JSCA is The Japan Smart Community Alliance (JSCA) was established in April 2010

${ }^{9}$ Jimbaran Hijau is located in the island of Bali and Bali is relatively a small island in the central of Indonesia but easily accessed by air and is serviced directly by all major airlines with daily flights from Australia, Europe, American and
}

extension of the space, which is to provide and improve the small cramped and crowded, serious pollution of the urban and the public service is of epoch-making significance. It extends the scope of urban services to the "last mile" of the urban, makes up for the inadequacy of urban planning, and promotes public participation in community construction and urban common maintenance." (LIU, 2017, p. 6).

Jimbaran Hijau ${ }^{9}$ people worked to develop the urban planning of their city. "So, they tried to set two strategies in creating a smart community in the development;

- Developing an education complex that is an international standard and consists of a full range of education level from the early stage up to university,

- Building a hive for start-up digital businesses which is dominated by the smart millennial generation."

After viewing the literature review that dealt with the concept with the smart community. It is necessary to know what these characteristics that mentioned to the smart community are.

Feng $^{10}$ and Jianhua ${ }^{11}$ determined the characteristics "depend on three features and the integration between them (Social world, Cyberworld and Physical world): (Xia \& Ma, 2011, p. 3)

1. A smart community consists of both human individuals and smart physical things as members that interact with each other.

2. The scales of smart communities vary case by case. One smart community may have only several members, while another may have a very huge number of members.

3. Smart communities are time-evolving. Thus, the scale of a smart community may change over time. Consequently, smart communities should have good scalability.

4. Smart communities are socially and physically aware systems.

5. It is not necessary for smart communities to be Internet-based (i.e. online). Some smart communities may function in (local) environments without connection to the Internet.

6. The lifecycle of smart communities could possibly be very long in some cases, while relatively short in others, depending on the application supported."

Now table 1-3 explains the importance of community initiatives that appear in Iraq with mentioned to the smart city factors and indicators.

It was mentioned to six strategies to achieve the smart communities in Article (Smart Communities as Hubs of Innovation) which are: See Figures 5 \& Figure 6.

most Asian counties facilitated by Ngurah Rai International Airport.

10 Feng Xia is professor in Dalian University of Technology, China.

${ }^{11}$ Jianhua Ma is Professor in Hosei University, Japan. 
1. Encourage start-ups

2. Partner with Academia

3. Engage Citizens

4. Boost the effectiveness

5. Support the business community

6. Create an interconnected, engage the community

According to the above, the research found six major factors as it was mentioned in Table (1-2), which are: (Wolfe, 2015)

1. Business Community

2. Scalability

3. Complexity

4. Connectivity

5. Capacity Building

\section{Community participation}

It was mentioned that all main factors of smart community focus on people.

What are the differences between smart people and smart community? At first glance, it could be the similarity between these two vocabularies. However, we can see that the participation of smart people for making a decision in their cities is a low according to the ladder of community participation because it is based on indicators working largely on the individual and not the team or community. To build the capacity of your community, it is necessary to improve the mechanism of development for individuals and groups. Smart people factors focus on how the man could play a role in his/her community while smart community factors focus directly on the group itself.

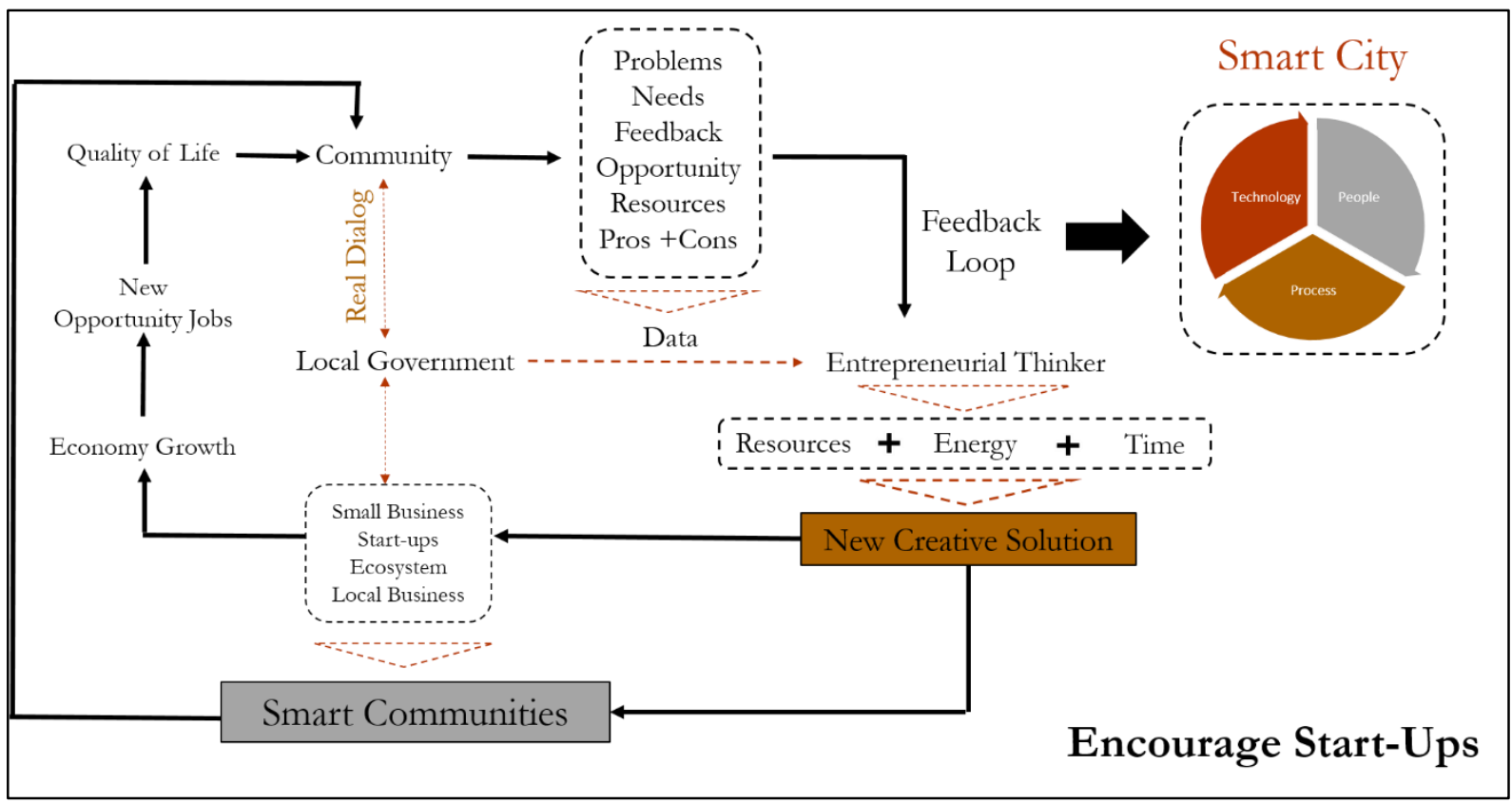

Figure 5: Smart Communities by encouraging Startups (by Authors) According to (Wolfe, 2015) 


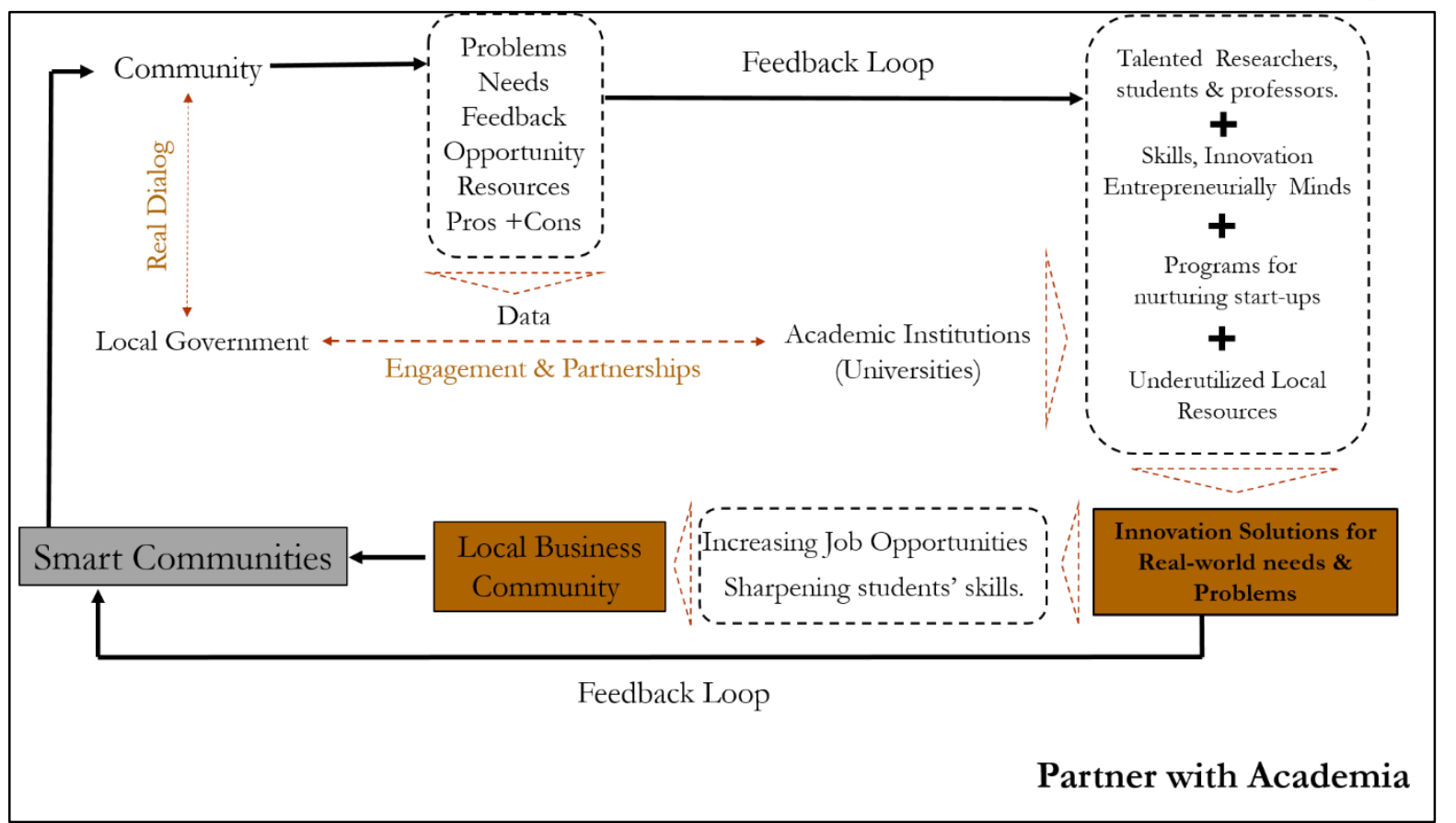

Figure 6: Smart Communities through a partner with academia (by Authors) According to (Wolfe, 2015)

Table 1-3: Iraqi Community initiatives with smart city indicators by Author

\begin{tabular}{|c|c|c|c|}
\hline Year & $\begin{array}{l}\text { Initiatives } \\
\text { Name }\end{array}$ & Description & Smart City Indicators \\
\hline $\begin{array}{l}2011- \\
\text { until } \\
\text { now }\end{array}$ & $\begin{array}{l}\text { TEDx } \\
\text { Baghdad }\end{array}$ & $\begin{array}{l}\text { Annual Event for one day } \\
\text { Goal: To highlight success } \\
\text { stories in the country. }\end{array}$ & $\begin{array}{l}\text { Entrepreneurship } \\
\text { Creativity } \\
\text { Productivity } \\
\text { Innovation spirit } \\
\text { Participation in public life } \\
\text { Public and social services } \\
\text { Capacity Building } \\
\text { Futurity } \\
\text { connectivity }\end{array}$ \\
\hline $\begin{array}{l}2012- \\
\text { until } \\
\text { now }\end{array}$ & Iraqi Builders & $\begin{array}{l}\text { Social entrepreneurship } \\
\text { group. } \\
\text { Goal: To help the poor by } \\
\text { building shelters and } \\
\text { providing food baskets } \\
\text { among other social initiatives }\end{array}$ & $\begin{array}{l}\text { Entrepreneurship } \\
\text { Housing quality } \\
\text { Creativity } \\
\text { Productivity } \\
\text { Participation in public life } \\
\text { Capacity Building } \\
\text { Connectivity } \\
\text { Public participation } \\
\end{array}$ \\
\hline $\begin{array}{l}2012- \\
\text { until } \\
\text { now }\end{array}$ & Fikra Space & $\begin{array}{l}\text { Online community for } \\
\text { coders and tech enthusiasts. } \\
\text { Goal: To develop the } \\
\text { technological ecosystem in } \\
\text { Iraq through workshops, } \\
\text { training, activities, } \\
\text { innovation and patent } \\
\text { applications }\end{array}$ & $\begin{array}{l}\text { Level of Qualifications } \\
\text { Creativity } \\
\text { Innovation spirit } \\
\text { Productivity } \\
\text { Affinity to lifelong learning } \\
\text { Flexibility } \\
\text { Education development } \\
\text { Capacity Building } \\
\text { Connectivity } \\
\text { Futurity }\end{array}$ \\
\hline $\begin{array}{l}\text { 2013- } \\
\text { until } \\
\text { now }\end{array}$ & $\begin{array}{l}\text { Startup } \\
\text { Weekend } \\
\text { Program }\end{array}$ & $\begin{array}{l}4 \text { teams in Baghdad, } \\
\text { Sulymani, Erbil, and Basrah } \\
\text { organized annual workshops } \\
\text { for two days of weekends. } \\
\text { Goal: To encourage Iraqi } \\
\text { Youth to start thinking for } \\
\text { their projects } \\
\text { To improve Iraqi youth the } \\
\text { concept of lean up and } \\
\text { startup, design thinking and } \\
\text { entrepreneurship }\end{array}$ & $\begin{array}{l}\text { Entrepreneurship } \\
\text { Level of Qualifications } \\
\text { Creativity } \\
\text { Innovation spirit } \\
\text { Productivity } \\
\text { Unemployment rate } \\
\text { Affinity to lifelong learning } \\
\text { Flexibility } \\
\text { Participation in public life } \\
\text { Public and social services } \\
\text { Capacity Building }\end{array}$ \\
\hline
\end{tabular}




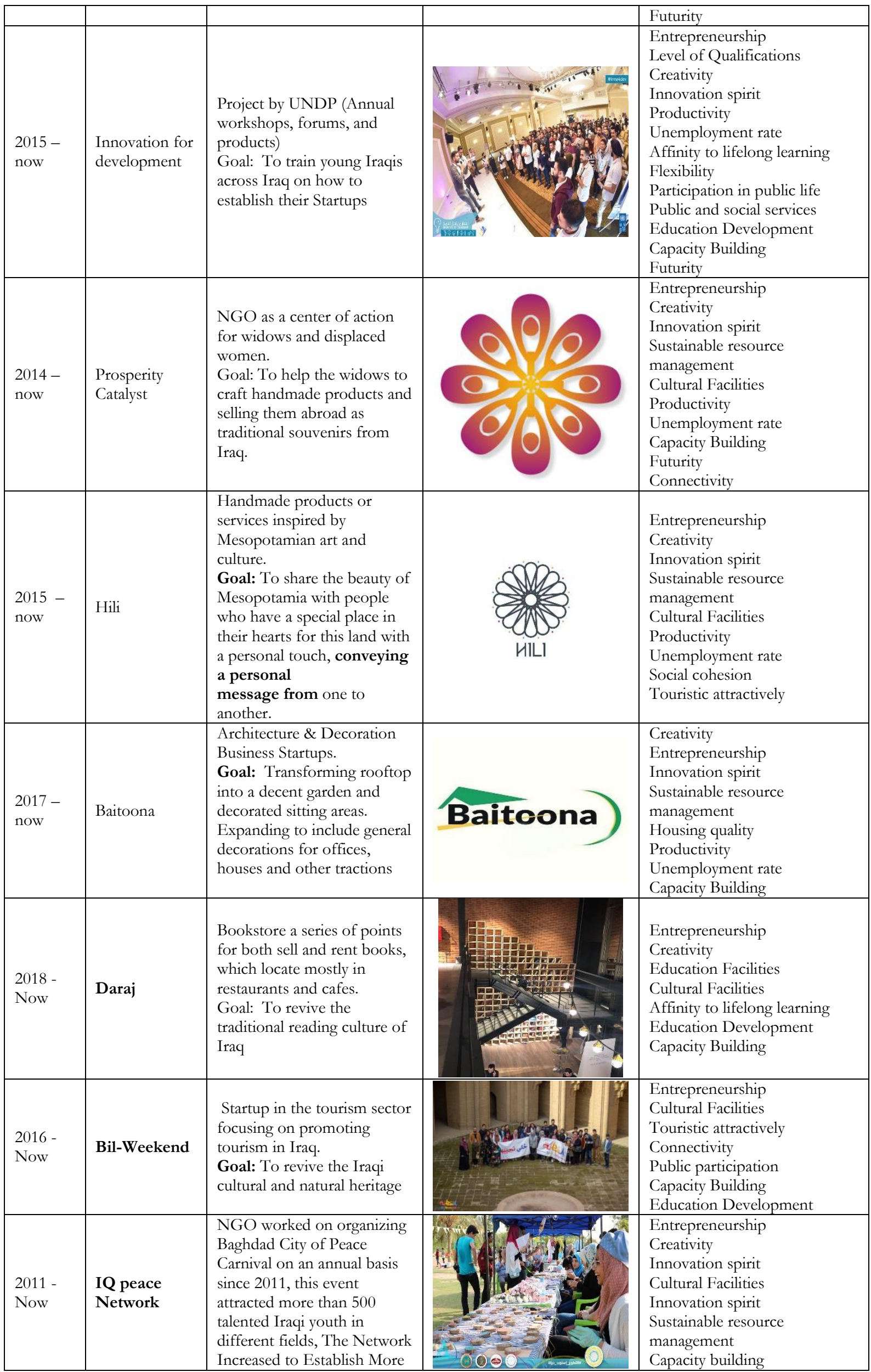




\begin{tabular}{|l|l|l|l|l|}
\hline 2015- & $\begin{array}{l}\text { Carnivals and different } \\
\text { projects in Iraq. } \\
\text { Goal: To create an } \\
\text { ecosystem for interactivity } \\
\text { and creativity } \\
\text { To improve the capacity } \\
\text { building of Iraqi youth } \\
\text { through workshops, events, } \\
\text { activities }\end{array}$ & $\begin{array}{l}\text { Connectivity } \\
\text { First kind of NGO as a } \\
\text { center for contemporary art. } \\
\text { Goal: To provide Baghdadi } \\
\text { Youth and women to } \\
\text { express their ideas through } \\
\text { annual exhibitions, public } \\
\text { performances, training, and } \\
\text { workshops }\end{array}$ \\
\hline Pait Tarkib participation \\
\hline 2017- \\
ow
\end{tabular}

\section{Conclusion}

Baghdad is a livable and vibrant city through its inhabitants. People continue to live, rejoice, celebrate, innovate and develop. The existence of the gap between the government and the residents has created an indirect incentive for people to initiate and carry out activities and projects without relying on the government. Some succeeded, some failed, and others still worked to achieve their goals.

The research emphasized that smart communities play an essential role in achieving smart city for people city not of thing. And thus, the smart community is the seventh factor of the smart city, its main indicators are Education Development, capacity building, public participation, Futurity, Scalability, and Aggregate of system. Also, it confirmed that:

- The rapid rhythm of life makes people losing life details, missing the human connectivity, focusing on global problems and ignoring local problems. While people could solve many of their local problems firstly, then solving global problems will be easier later on.

- Smart city depends on three pillars: people, data, and technology. Also, it based on connections, open data, and sensors. People is a double coded factor because they are effective and affected. People in a smart city are as voluntary sensors for feeding the smart system with information and participate to make the decisions in their city.

- To achieve the smart economy in Iraq, we should be focusing on entrepreneurship and the spirit of innovation and direct it towards the idea of self- employment and creating Innovative projects that solve the problems of life rather than work in the public sector. Especially, Iraqi youth began to improve themselves by volunteerism, participation in workshops and courses in leadership and communication forms, teamwork. That means the next generation has the ability to play a good role in economic development.

- Investment of youth in economic decisionmaking will re-energize and stimulate the economy and foster confidence among the large, medium and startup companies. So, it requires public and private sectors to support small startups and business, and facilitate their mission, to ensure a thriving economic market for the next generation.

- A sustainable smart city requires to configure a sustainable human base that possesses the skills and awareness of the people to participate in decision-making and to achieve a satisfactory quality of life for themselves because usership and prosumers are most sides that touch the sustainability of human life.

- Sustainable environmental management requires participatory action between government and community. All stakeholders have a responsibility to achieve the smart environment because citizens are the producers and consumers at the same time.

- It is very important for the community to have sufficient awareness and culture about environmental issues. For example, water contamination, sewage systems, recycling and 
use of waste, air pollution, and others. if there is no social initiatives and awareness by people through volunteerism and NGOs About environmental issues and solutions, government effort may be lost in vain.

- Smart mobility is a standard for measuring the quality of life in the city and also good mobility is an attraction for tourism and economic exchange with foreigners. The transport system should be sustainable and innovative. It should also take care of the safety of daily and occasional commuters within and outside the city.

- It is not necessarily that using the most technologically advanced transportation means to be smart, but it should be achieved through communication and connection between the urban foci of the city in suitable ways and appropriate means to privacy and nature of the area.

- If the mobility in the city is not efficient, it may cause environmental and pollution problems on one hand, and economic and social aspects on the other. Mobility may be a standard for measuring the quality of life in the city and also good mobility is an attraction for tourism and economic exchange with the outside

- Baghdad has many problems in Networks and transportations. These problems need large efforts from government and community. It is not easy to achieve smart mobility individually without government planning and community will. Most streets in Baghdad are not suitable for walking. The lack of law and regulation.

- Smart living indicators in the smart city focuses on investing people power and create a sense of community and belonging to a place. Social capital depends on three pillars, are Knowledge, intelligence and creativity.

- It confirms that the achievement of quality in education, health, housing, poverty reduction and protection of tourist sites in Iraq are not the responsibility of the authorities and governments alone, citizens should assume the role of participants through social actions, initiatives, small business, and so on.

- The principles of Smart city encourage decision making from bottom to top that depends largely on people's satisfaction, the nature of their needs and their sense of belonging to these places. Because Feed-back loop is essential in the smart city to ensure its sustainability and effectiveness by/for people more than things.

- The connectivity by people and technology plays a good role in decision making. Community participation will create transparency and trustiness, and decrease the gap between the people and their governments.

- It is important to note that connectivity and communication among young people in Baghdad through activities, social works, volunteerism and events with using of technology as a secondary mean that creates the smartness of people and as a result contributes to the realization of the smart city in a way that ensures its sustainability because it stems from the inhabitants and the users themselves.

- Smart community term mentions three aspects. Firstly, it is political; secondly, it is technological; and thirdly, it is social. The interaction and connectivity between three aspects will create a sense of community and a sense of belonging that assures the sustainability and smartness in the city.

\section{References}

1. Aggarwal, V., 2019. Smart Cities in India: Branded or Brain-dead?. Karlsruhe, REAL CORP Conference 2019.

2. AL-HILLY, A., 2018. Youth and Entrepreneurship Outlay in Iraq, Baghdad: Zain Group Company - Iraq.

3. Al-Kamoosi, N. \& Al-Ani, M. Q., 2019. The Role of Spirit of Place to Achieve Emotional Smart Cities. Karlsruhe, Real Corp 24th International Conference on Urban Planning, Regional Development and Information Society.

4. Angelidou, M., 2017. The Role of Smart City Characteristics in the Plans of Fifteen Cities. Journal of Urban Technology.

5. Benjamin, R. M., 2011. Principles of the Community Engagement, s.l.: CTSA Community Engagement Key Function Committee.

6. Bruce, S. \& Yearley, S., 2006. The Sage Dictionary of Sociology. First ed. London, UK: SAGE Publications Ltd.

7. Counsell, J., 2017. The Potential of Living Labs for Smart Heritage Building Adaptation. Advanced Technologies for Sustainable Systems, Volume 978, pp. 41-50.

8. Giffinger, R. \& Fertner, C., 2007. Smart cities: Ranking of European medium-sized cities, Vienna: the Centre of Regional Science (SRF),

9. Gopeni, A., 2016. A Feedback Loop Model to Facilitate Communication Between Citizens and Local Government in a Smart City. East London: University of Fort Hare.

10. Gupta, S., Mustafa, S. Z. \& Kuma, H., 2017. Advances In Smart Cities. UK: Taylor \& Francis Group.

11. Hollands, R. G., 2015. Critical Interventions Into Corporate Smart City. Cambridge Journal of Regions, 8(1), pp. 61-77.

12. International Center for Communications, 1997. Smart Communities Guidebook: Building Smart Communities, how California's Communities Can Thrive in the Digital Age. San Diego: International Center for Communications, 
College of Professional Studies and Fine Arts, San Diego State University.

13.Iraqi Ministry of Planning, 2017. Annual Statistical Report 2017, Baghdad: Iraqi Ministry of Planning.

14.Jacobs, J., 1961. The Death and Life of Great American Cities. New York: Jane Jacobs.

15.JSCA, 2015. SMART COMMUNITY -Japan's Experience-, Tokyo: Japan Smart Community Alliance.

16. Khalilnezhad, S. T., 2019. A Conceptual Framework for the Utilisation of ICT in Participatory Planning. Karlsruhe, REAL CORP 2019 Proceedings.

17. Lindskog, H., 2005. Smart communities initiatives. Washington DC, The Information Institute, pp. 83-101.

18.LIU, C., 2017. Chinese Smart Community: "Last Mile" of Serving Public Life. Oregon, ISOCARP Conference .

19. MacDonald, J. A., 2000. Smart communities : report of the Panel on Smart Communities., Ottawa: National government publication.

20. Merriam-Webster， 2018. Merriam-Webster Dictionary Website. [Online] Available at: https://www.merriamwebster.com/dictionary/participation [Accessed 28 2018].

21. Monzon, A., 2015. Smart Cities Concept and Challenges: Bases for the Assessment of Smart City Projects. Springer International Publishing Switzerland, p. 17-31.

22. Murgante, B., 2019. Smart City or Urban Science. Karlsruhe, REAL CORP Conference 2019.
23. PIRACHA, A. \& KUMAR, K., 2017. Community Participation and ICT-driven Governance in Smart Cities Mission of India. Oregon, ISOCARP-OAPA Conference 2017.

24. Ottenburger, S. S. \& Ufer, U., 2019. Abstract Smart Space and Concrete Risks. Karlsruhe, REAL CORP 2019 Proceedings.

25. Pahuja, A. \& Sanjeev, R., 2015. Introduction to Entrepreneurship. Ghaziabad, Institute of Management Studies.

26. Ryser, J., 2019. City OF Things or City FOR People?. Karlsruhe, Real Corp 24th International Conference on Urban Planning, Regional Development and Information Society.

27. Turnbull, J., 2010. OXFORD Advanced Learner's Dictionary of Current English. 8th edition ed. New York: Oxford University Press.

28. United Nation, 2018. Sustainable Development Goals, s.l.: United Nations.

29. Wolfe, B., 2015. Smart Communities as Hubs of Innovation.

[Online]

Available at: https://medium.com/esriinsider/smart-communities-as-hubs-ofinnovation-60a5242d 2104 [Accessed 29 July 2019].

30.Xia, F. \& Ma, J., 2011. Building Smart Communities with Cyber-Physical Systems. Beijing, Association for Computing Machinery.

31.Zhu, X. \& Dai, S., 2017. Smart communities: the coexisting of the intelligent future and the intimate neighborboods past (Built Heritage Communities' Future). Oregon, ISOCARP -COAPA Conference2017. 